\title{
Live and Inactivated Salmonella Enteritidis Vaccines: Immune Mechanisms in Broiler Breeders
}

\author{
Letícia Dal Bérto ${ }^{*}$, Breno C. B. Beirão ${ }^{2 *}$, Tobias Fernandes Filho²,3, Max Ingberman²,3, \\ Celso Fávaro Jr. ${ }^{2,3}$, Rosangela Tavella1, Rebeca Buest de Mesquita Silva1, \\ Luiz Felipe Caron ${ }^{3 \#}$ \\ ${ }^{1}$ Campus UP, Universidade Positivo, Curitiba, Brazil \\ ${ }^{2}$ Imunova Análises Biológicas, Curitiba, Brazil \\ ${ }^{3}$ Departamento de Patologia Básica, Universidade Federal do Paraná, Curitiba, Brazil \\ Email: Ifcaron@ufpr.br
}

Received 1 October 2015; accepted 31 October 2015; published 3 November 2015

Copyright (C) 2015 by authors and Scientific Research Publishing Inc.

This work is licensed under the Creative Commons Attribution International License (CC BY). http://creativecommons.org/licenses/by/4.0/

(c) (i) Open Access

\begin{abstract}
Salmonella is a ubiquitous pathogen which, in addition to causing poultry diseases, has a growing zoonotic impact. It has demanded the implementation of diverse control strategies, in which vaccines play a major role. The understanding of the immune pathways elicited by the different vaccines is important, contributing for the establishment of strong immune correlates of protection, for instance. With the purpose of determining the dynamics of the humoral and cellular immune responses to vaccination, broiler breeders (Cobb Slow) were immunized with live or inactivated vaccines against Salmonella Enteritidis. Lymphocyte and macrophage subsets were analyzed in the peripheral blood by flow cytometry and antigen-specific circulating IgY and mucosal IgA were quantified. The markers analyzed by flow cytometry were CD8/CD28, CD4/TCRVB1, Kul/ MHC II and Bu-1. Both live and inactivated vaccines induced an increase in the proportion of circulating monocytes $\left(\mathrm{Kul}^{+} \mathrm{MHCII}^{+}\right)$in some time points compared to non-vaccinated controls. However, whereas the live vaccine leads to an increase in $\mathrm{CD8}^{-} \mathrm{CD}^{2} 8^{+}$and $\mathrm{Bu}-1^{+}$lymphocytescompared to the control group, the inactivated vaccine prompteda reduction in the percentage of se-

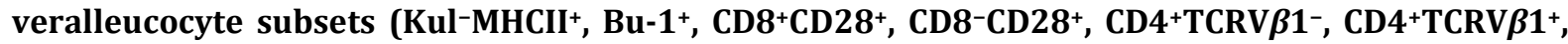
CD4-TCRV $\beta 1^{+}$) after the boost dose. Both vaccines induced specific serum IgY and mucosal IgA production; however, the inactivated vaccine stimulated higher titers in a shorter period. These results contribute to the understanding of mechanisms of action of live and inactivated Salmonella vaccines in chickens.
\end{abstract}

\footnotetext{
*These authors contributed equally.

"Corresponding author.
}

How to cite this paper: Bérto, L.D., Beirão, B.C.B., Filho, T.F., Ingberman, M., Fávaro Jr., C., Tavella, R., de Mesquita Silva, R.B. and Caron, L.F. (2015) Live and Inactivated Salmonella Enteritidis Vaccines: Immune Mechanisms in Broiler Breeders. World Journal of Vaccines, 5, 155-164. http://dx.doi.org/10.4236/wjv.2015.54018 


\section{Keywords}

\section{Salmonella Enteritidis, Humoral and Cellular Immunity, Live Vaccine, Bacterin, Broiler Breeders}

\section{Introduction}

Salmonella spp. remains as one of the main causes of alimentary infection in humans. Poultry meat and eggs are constantly linked to clinical cases. The success of control strategies for salmonellosis in chickens is associated with several factors, among which is the control of bacterial contamination at its sources [1]. The reduction of novel infections in positive flocks is an important part of control programs for Salmonella, to which immunization has a relevant role [1].

Among the most relevant serovars is $S$. Enteritidis, with its prevalence reaching more than $1 \%$ (up to $8 \%$ ) of breeding flocks in several European countries [1]. In Brazil, at the point of sale, up to $30 \%$ of food products destined to human consumption can be contaminated with Salmonella spp., with high antibiotic resistance [2]-[4]. The growing presence of antibiotic resistant Salmonella in outbreaks aggravates the public health concern [5]. The majority of human cases in Brazilare caused by $S$. Enteritidis [6].

The immunization of parent flocks with live and inactivated vaccines is a common practice inanimal biosecurity control programs of $S$. Enteritidis and $S$. Typhimurium, aiming to reduce the excretion and the contamination of the carcass and eggs [7]. Both the live and inactivated vaccine types discussed in this work have been shown to be effective in inducing protection and inreducing organ colonization after challenge. However, previous studies have not yet explored the immune mechanisms through which these vaccines exert their effects [8]-[11]. Indeed, the immune mechanisms involved in the protection against Salmonella in poultryare not well known [12] [13].

This study had the objective of testing the immune effects of live and inactivated vaccines against Salmonella in broiler breeders. Several cellular subsets and antibody titers were analyzed serially in the peripheral blood and mucosae with the intent of clarifying the immune responses underlying the protection conferred by vaccination.

\section{Materials and Methods}

\subsection{Animals and Experimental Design}

One hundred and fifty birds of the Cobb broiler breeder lineage were divided equally and randomly into 3 groups. The "negative control" group did not receive any treatment throughout the experiment. The "live vaccine" group received three doses of said compound on days 1, 42 and 112 of age. The "inactivated vaccine" group was inoculated on days 84 and 126 of age. The experimental protocol is illustrated in Figure 1.

Procedures with animals followed ethical standards and were approved by the Bioethics Committee from Universidade Positivo, protocol 142/2013.

The inactivated vaccine (AviPro ${ }^{\circledR} 109$ SE4, Lohmann Animal Health) was injected subcutaneously (0.25 $\mathrm{ml} /$ bird), in the dorsal region of the neck, using disposable needles. The vaccine was used according to the manufacturer's instructions. AviPro ${ }^{\circledR} 109$ SE4 contains Salmonella Enteritidis of the phagotypes 8, 24, 14B e 23 in oil emulsion. The live vaccine (AviPro ${ }^{\circledR}$ Salmonella VAC E, Lohmann Animal Health) is composed of Salmonella Enteritidis (Sm24/Rif12/Ssq), which is a mutant strain derived from metabolic alterations (Metabolic Drift Mutants) (EFSA, 2004). The first dose was administered via large particle aspersion; the second and third doses were administered via drinking water.

\subsection{Microbiological Analyses}

Presence of live Salmonella was assessed in the environment and in birds throughout the experiment. Previous to housing, presence of Salmonella was verified on the surfaces of the cages, in the water and on the air filters. In the birds, swabs of cloaca were analyzed for Salmonella on day 1 and at 6, 12 and 16 weeks of age. Microbiological isolation and bacterial analyses were made by Laboratório Porto Belo (Porto Alegre, Brazil). 

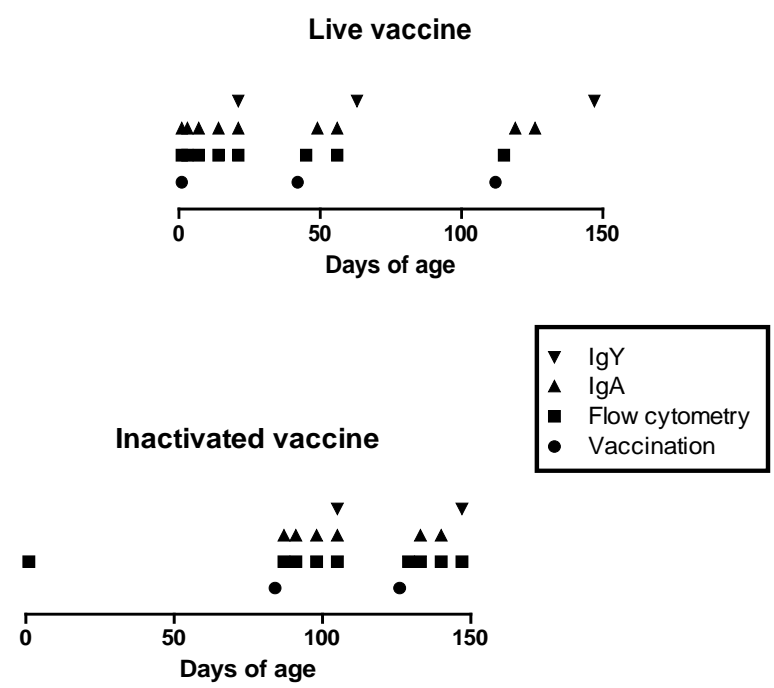

Figure 1. Experimental protocol. Dates of vaccination and sample collection for the referred tests. Collection of samples for live and inactivated (bacterin) vaccines followed different protocols, according to the vaccination schedule.

\subsection{Assessment of Immune Parameters-Cellular Immune Response Analysis by Flow Cytometry}

Blood collection for flow cytometry immunophenotyping was performed by wing vein puncture with heparinized syringe. For the live vaccine, blood collections were made before the first vaccine dose, then 3, 7, 14 and 21 days after the first dose, 3 and 14 days after the second dose and 3 days after the third dose. After immunization with the inactivated vaccine, samples were collected on day 1, and then 3, 7, 14 and 21 days after both doses (Figure 1). The same animals were studied throughout the experiment, allowing a continuous analysis of the fluctuation of immune parameters.

Flow cytometry was performed as previously described [14]. Briefly, mononuclear cells from peripheral blood were separated by Histopaque-1077 (Sigma). The resulting buffy coat was fixed in paraformaldehyde, blocked with $1 \%$ bovine serum albumin in phosphate buffered saline (PBS) and $10^{6}$ cells/test were stained with the primary antibodies. Antibodies were used at $0.5 \mathrm{mg} / \mathrm{ml}$ (FITC conjugated antibodies) or $0.1 \mathrm{mg} / \mathrm{ml}$ (PE and PerCP-Cy 5.5 conjugated antibodies). Cells were gated on the $\mathrm{CD} 45^{+}$region and analyzed for their expression of CD4/TCRV $\beta 1$; CD8/CD28; Kul [macrophage marker]/MHCII; Bu1 [B lymphocyte marker]. All primary antibodies were from Southern Biotechnology. All samples were analyzed within two hours of staining. Flow cytometry was performed on a FACSCalibur (Becton Dickinson). At least $10^{4}$ events in the lymphocyte quadrant were acquired (based on forward and side scatter characteristics). Data was analyzed on FlowJo (TreeStar).

\subsection{Assessment of Immune Parameters-IgY and IgA Quantification by ELISA}

For the detection of local secretory IgA, ten animals per treatment were analyzed. $200 \mu \mathrm{l}$ of intestinal content was aspirated from the cloaca of each bird using a nasogastric probe $\left(n^{\circ} 10\right)$. The sample was homogenized with $0.5 \mathrm{ml}$ of PBS and $0.02 \%$ sodium azide. The suspension was centrifuged at $7000 \times \mathrm{g}$, the supernatant was collected and stored at $-18^{\circ} \mathrm{C}$ until analysis. Quantification of intestinal antigen-specific IgA was carried out by antibody capture ELISA (enzyme-linked immunosorbent assay) [15]. 96-well plates were sensitized with $50 \mu \mathrm{l}$ of lipopolysaccharide (LPS) extracted from the vaccine strain (AviPro ${ }^{\circledR}$ Salmonella VAC E). The plate was blocked with $1 \%$ casein in PBS. The extract from intestinal contents was added (100 $\mu \mathrm{l} /$ well $)$ and incubated for $2 \mathrm{~h}$ at $37^{\circ} \mathrm{C}$. The plate was washed five times with TBST (50 mM Tris, $150 \mathrm{mM} \mathrm{NaCl}, 0.05 \%$ Tween 20, pH7.4). The anti-IgA HRP conjugated secondary antibody (AbD Serotec) was added for $1 \mathrm{~h}$ at $37^{\circ} \mathrm{C}$. Plates were washed again and the reaction was developed using 3,3',5,5'-tetramethylbenzidine (TMB) (Sigma) in citrate buffer (0.1 $\mathrm{mg} / \mathrm{ml}$ of TMB in $100 \mathrm{mM}$ sodium citrate, $100 \mathrm{mM}$ monobasic sodium phosphate, $0.0006 \%(\mathrm{~m} / \mathrm{v})$ of hydrogen peroxide, $\mathrm{pH}$ 5.2). The reaction was stopped with $2 \mathrm{M}$ sulphuric acid and absorbance was read at $450 \mathrm{~nm}$ in a 
microplate reader (Biorad). The threshold for positivity was $\geq 0.274$. Samples were collected at the ages of 1 day (before vaccination), 3, 7, 14, 21, 49, 56, 119 and 126 days for the chickens that received the live vaccine and the respective control group. For the animals immunized with the inactivated vaccine, collection of feces happened on days 87, 91, 98, 105, 133 and 140 of age (Figure 1).

For the detection of serum IgY, blood collection was performed by wing vein puncture. Serum was separated and kept at $-18^{\circ} \mathrm{C}$ until analysis in sterile tubes. Twenty three birds per treatment were sampled. From live vaccine-treated animals and its control group, samples were collected on days 21, 63 and 147 of age. From the inactivated vaccine group, samples were collected on days 105 and 147 (Figure 1). Salmonella specific antibodies were measured in the serum using a commercial ELISA kit for group D Salmonella LPS (BioCheck). The kit was used according to the manufacturer's instructions. The threshold for positivity was $\geq 654$.

\subsection{Statistical Analysis}

Treatments were compared by a two-way Analysis of Variance (ANOVA) with Bonferroni post-hoc test $(P<$ 0.05). Analyses and graphs were made using GraphPad Prism Software (GraphPad Software, Inc.).

\section{Results}

\subsection{Microbiological Analyses}

No Salmonella was isolated from cages, water, air filter or from the cloaca of birds throughout the experiment. This is in accordance with a previous study, which did not detect the mutant drift variant bacteria after immunization with the live vaccine [8].

\subsection{Peripheral Blood Immune Cells}

In chickens immunized with the live vaccine, proportions of monocytes $\left(\mathrm{Kul}^{+} \mathrm{MHCII}^{+}\right.$, on days 3 and 116), B-lymphocytes (Bu-1 $1^{+}$, on day 116$)$ and $\mathrm{CD}^{-} \mathrm{CD}^{-} 8^{+}$cells (on day 3) were raised following vaccination compared to the control group (Figure 2). Following bacterin immunization, only monocytes (on days 91, 98, 129 and 133) and $\mathrm{CD}^{-}{ }^{-} \mathrm{TCRV} \beta 1^{+}$(on day 87) were increased in peripheral blood, whereas $\mathrm{Kul}^{-} \mathrm{MHCII}^{+}$, B-lymphocytes, $\mathrm{CD}^{+}{ }^{+} \mathrm{CD} 28^{+}, \mathrm{CD} 8^{-} \mathrm{CD} 28^{+}, \mathrm{CD} 4^{+} \mathrm{TCRV} \beta 1^{-}, \mathrm{CD} 4^{+} \mathrm{TCRV} \beta 1^{+}$and $\mathrm{CD} 4^{-} \mathrm{TCRV} \beta 1^{+}$were reduced at different time points compared to the control group following vaccination, always in the two collection points following vaccine boost (days 129 and 133) (Figure 3).

\subsection{Serum IgY}

Anti-Salmonella-specific serum IgYtiterswere increased after immunization and are shown in Table 1(a) and Table 1(b).

\subsection{Local Secretory IgA}

Anti-Salmonella-specific fecal IgA titers were also increased after immunization and are shown in Table 2(a) and Table 2(b).

\section{Discussion}

\subsection{Live Vaccine}

Immunization with the live Salmonella vaccine did not cause environmental shedding of the bacteria, probably due to low persistence of the mutant drift variants outside the host. The immunization led to an increase in the percentage of circulating monocytes $\left(\mathrm{Kul}^{+} \mathrm{MHCII}{ }^{+}\right) 6$ days after the first dose (day 7) and 4 days after the third inoculation (day 116) in comparison to the control (Figure 2). B lymphocytes were also increased relative to the control group on day 116 , whereas $\mathrm{CD}^{-} \mathrm{CD}^{-} 8^{+}$cells showed increased proportions on day 3 , only 2 days after immunization.

After a Salmonella infection, there is a rapid influx of macrophages into the intestinal lamina propria and these phagocytes can be found until 6 days post-infection in large amounts [16]. The immune response against $S$. Typhimurium, for example, relieslargely on macrophages in hatchlings [17], which seems to corroborate our find- 


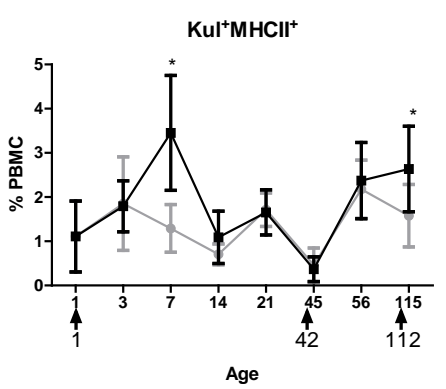

$\mathrm{CD}^{+} \mathrm{CD} 28^{-}$

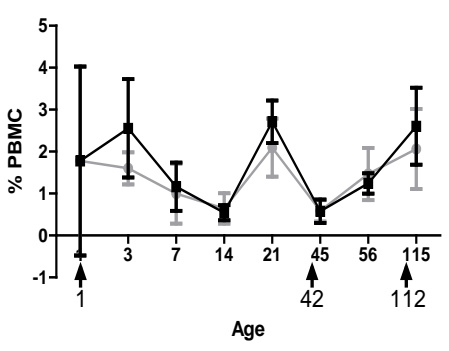

$\mathrm{CD}^{+}{ }^{+} \mathrm{TCRV}_{\beta} \mathrm{1}^{-}$

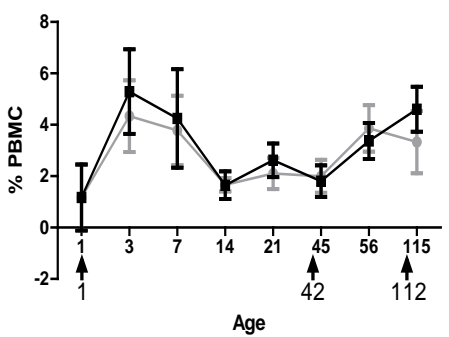

$\mathrm{Kul}^{-} \mathrm{MHCII}^{+}$

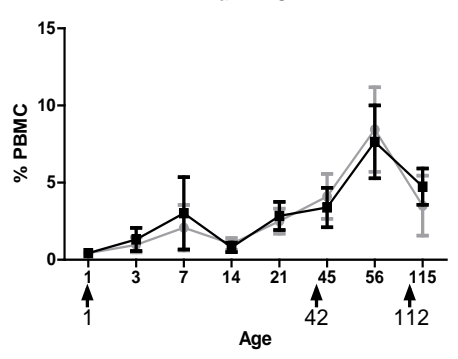

$\mathrm{CD}^{+} \mathrm{CD}^{-8^{+}}$

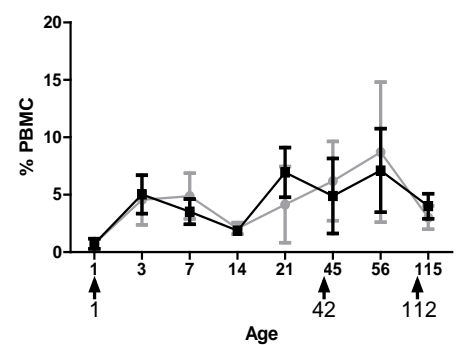

$\mathrm{CD}^{+}{ }^{+} \mathrm{TCRV} \beta 1^{+}$

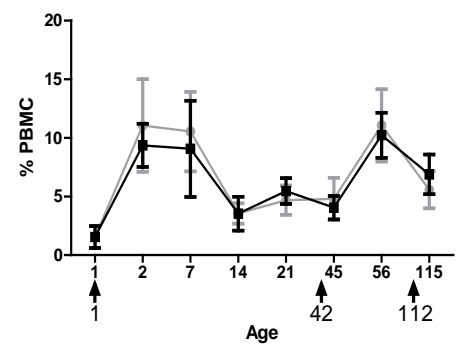

Bu-1 ${ }^{+}$

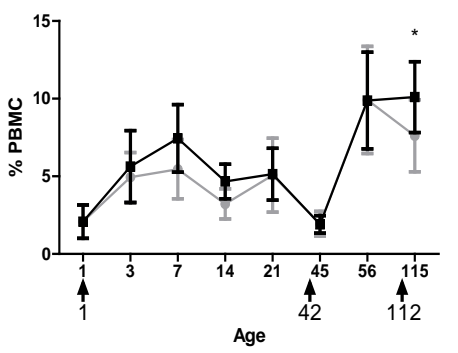

$\mathrm{CD}^{-} \mathrm{CD}^{\circ}{ }^{+}$

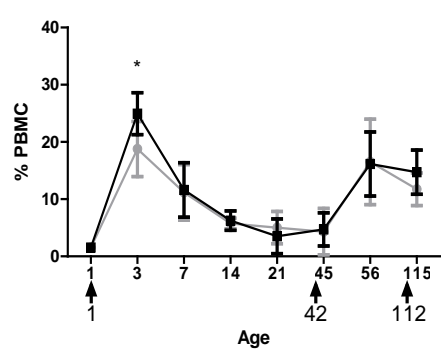

CD4TCRV $\beta 1^{+}$

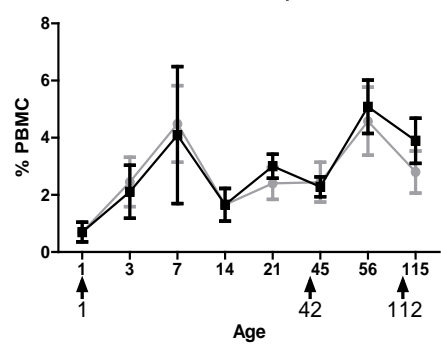

Figure 2. Peripheral immune cells in chickens immunized with the live vaccine. Leukocyte subsets are shown as the percentage of positive cells in relation to total peripheral blood mononuclear cells (PBMC). The grey line indicates the unvaccinated control. The black line indicates the vaccinated group. The $\mathrm{x}$-axis shows the age of the chickens. The arrows indicate the dates the animals were immunized, and the ages of the birds at that stage are shown beneath the arrows. Statistically significant differences between the control and the immunized groups at a given date are shown with an asterisk above the graph. Results shown as average \pm SD.

ings. The detection of the pathogen in the intestine by pattern recognition receptors, many of which are expressed abundantly in macrophages, is crucial for the initiation of the immune response against Salmonella and the subsequent activation of the cells of the adaptive immune system [18].

Tissue demand for B-lymphocytes is also increased following Salmonella challenge [16]. There is an increased proliferation of B-lymphocytes 21 days after contact with the antigen [19], which may explain the increased levels of this cell population after immunization with the live vaccine.

$\mathrm{CD}^{+} 8^{+} \mathrm{T}$ cells are $\mathrm{T}$ lymphocytes that have not yet undergone terminal differentiation, being still capable of replication in response to stimulus. This subset of cells includes activated lymphocytes, naïve and memory cells [20]-[22]. In our work, the percentage of CD8 ${ }^{-} \mathrm{CD}^{+} 8^{+} \mathrm{T}$ cells shifted very rapidly after immunization with the live vaccine, indicating that there was an increased proliferative response subsequently to vaccination. Indeed, $\mathrm{CD}^{+}$and $\mathrm{CD}^{+} \mathrm{T}$ cells are known to proliferate after mucosal immunization with Salmonella in humans, being also capable of increasing IFN- $\gamma$ production [23]. Corroborating our results, a previous work also could not find differences on TCRV $\beta 1^{+}$cells in the peripheral blood after immunization with an oral live vaccine [24].

An increase in the circulating Salmonella-specific IgY could be observed even after the first dose of the live vaccine (Table $1(\mathrm{a})$ ), even though the threshold of positivity (titer $>654$ ) was not crossed at that initial point. The titer was further increased with subsequent administrations. Oral immunization with live Salmonella is known to enhance serum IgG levels, in support of our results [23], whereas the use of an inactivated vaccine 


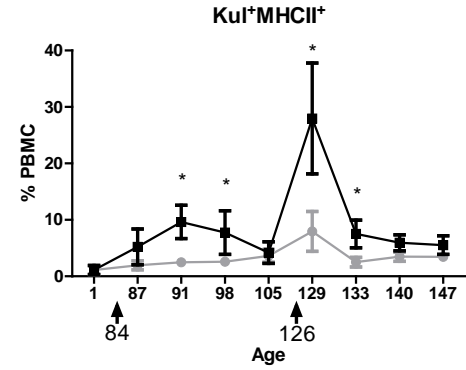

$\mathrm{CD}^{+} \mathrm{CD} 28$

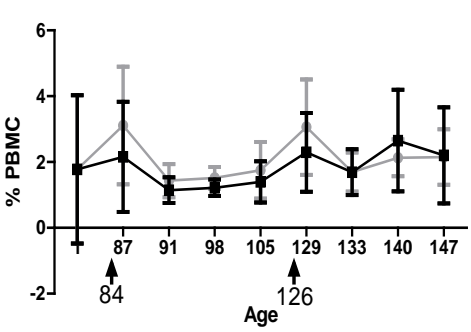

$\mathrm{CD}^{+}{ }^{+} \mathrm{TCRV}_{\beta} 1^{-}$

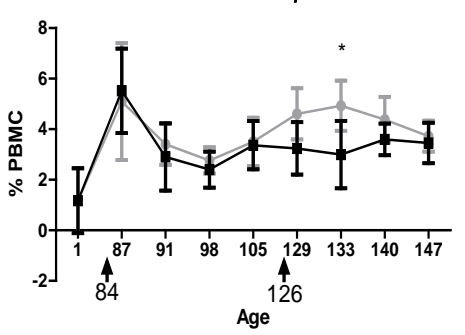

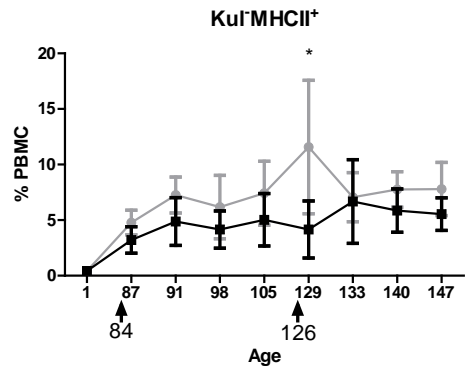

$\mathrm{CDB}^{+} \mathrm{CD}^{-8^{+}}$

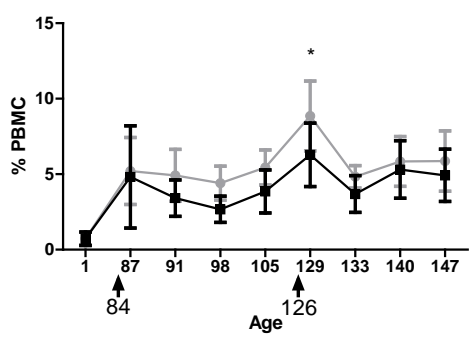

$\mathrm{CD}_{4}{ }^{+} \mathrm{TCRV}_{\beta} 1^{+}$

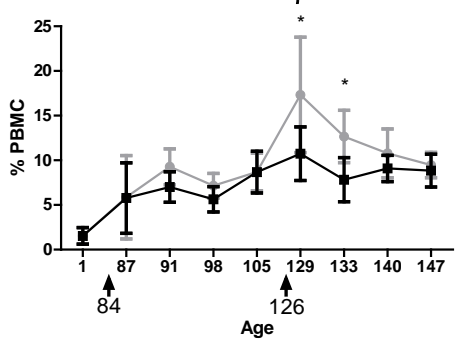

Bu-1 $^{+}$

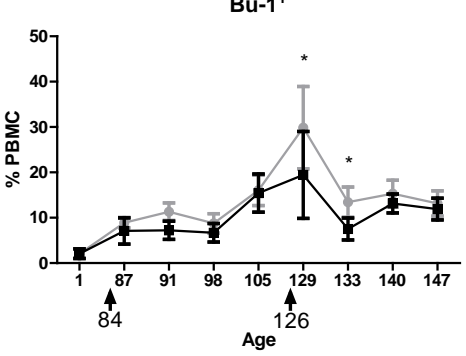

$\mathrm{CD8}^{-} \mathrm{CD}^{+}{ }^{+}$

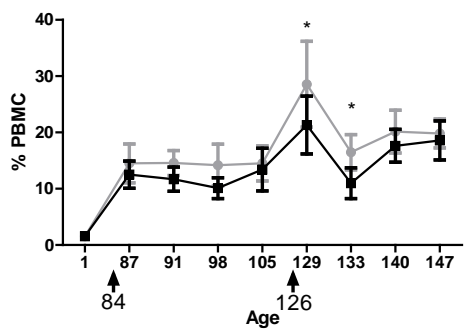

CD4-TCRV $\beta 1^{+}$

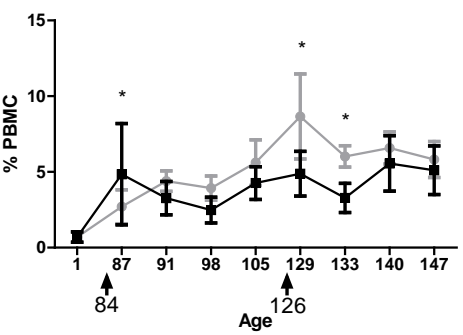

Figure 3. Peripheral immune cells in chickens immunized with the bacterin vaccine. Leukocyte subsets are shown as the percentage of positive cells in relation to total peripheral blood mononuclear cells (PBMC). The grey line indicates the unvaccinated control. The black line indicates the vaccinated group. The $\mathrm{x}$-axis shows the age of the chickens. The arrows indicate the dates the animals were immunized, and the ages of the birds at that stage are shown beneath the arrows. Statistically significant differences between the control and the immunized groups at a given date are shown with an asterisk above the graph. Results shown as average \pm SD.

Table 1. Serum immunoglobulin (Ig)Y titers following immunization with live (a) or bacterin (b) vaccines. Results are shown as averages of titers. The columns refer to the age of the chickens at the time of blood collection. Statistically significant differences at a given date are shown with different superscript letters next to the averages.

(a)

\begin{tabular}{cccc}
\hline Group & $\mathbf{2 1 ~ d}$ & $\mathbf{6 3} \mathbf{d}$ & $\mathbf{1 4 7} \mathbf{d}$ \\
\hline Control & $2.65^{\mathrm{b}}$ & $9.00^{\mathrm{b}}$ & $92.40^{\mathrm{b}}$ \\
Live vaccine & $11.96^{\mathrm{a}}$ & $892.87^{\mathrm{a}}$ & $1468.70^{\mathrm{a}}$ \\
Probability & 0.0007 & $<0.0001$ & $<0.0001$ \\
\hline
\end{tabular}

(b)

\begin{tabular}{ccc}
\hline Group & $\mathbf{1 0 5} \mathbf{d}$ & $\mathbf{1 4 7 ~ d ~}$ \\
\hline Control & $35.00^{\mathrm{b}}$ & $92.40^{\mathrm{b}}$ \\
Bacterin & $3295.30^{\mathrm{a}}$ & $3279.20^{\mathrm{a}}$ \\
\hline Probability & 0.0007 & $<0.0001$ \\
\hline
\end{tabular}


orally failed to affect serum IgY [25]. The mutant Salmonella variant used for live vaccination shows limited persistence and tissue invasion capacities (Gantois et al. 2006), supporting the possibility that astrain that is restricted to the mucosa is capable of serum IgY production.

The live vaccine was also able to induce higher levels of intraluminal IgA antibodies in relation to control (Table 2(a)), crossing the positivity threshold (0.274) on day 56. The importance of antibodies in Salmonella clearance is controversial, but it is known that bacterial challenge induces IgA in serum and that high antibody responses are associated with lower numbers of $S$. Typhimurium in the gut lumen [26]. Therefore, the presence of IgA in the lumen after mucosal immunization reinforces the importance of this antibody isotype for protection against Salmonella.

In summary, the mechanism of action of the live vaccine may rely on the production of antibodies, both systemically and secreted at mucosal sites. Cellular immune responses, especially those dependent on monocytes/ macrophages, are likely to be important for protection, especially at early time points after infection. Efficacy of vaccination was not assessed, but these data may assist in the understanding of the known differences between live and inactivated vaccines in conferring protection [27].

\subsection{Innactivated Vaccine}

The cellular responses following immunization with the inactivated vaccine are considerably different from those seen after the live vaccine administration. $\mathrm{Kul}^{-} \mathrm{MHCII}^{+}$, B-lymphocytes $\left(\mathrm{Bu}-1^{+}\right), \mathrm{CD}^{+} \mathrm{CD}^{2} 8^{+}, \mathrm{CD}^{-} \mathrm{CD}^{-} 8^{+}$, $\mathrm{CD} 4^{+} \mathrm{TCRV} \beta 1^{-}, \mathrm{CD} 4^{+} \mathrm{TCRV} \beta 1^{+}$and $\mathrm{CD} 4^{-} \mathrm{TCRV} \beta 1^{+}$were reduced in the peripheral blood of vaccinated animals in comparison to control animals following the administration of the second dose of the inactivated vaccine. $\mathrm{CD} 4 \mathrm{TCRV}^{-} 1^{+}$was briefly increased after the first dose, while $\mathrm{Kul}^{+} \mathrm{MHCII}^{+}$were increased after both inactivated vaccine doses (Figure 3 ).

The importance of monocytes $\left(\mathrm{Kul}^{+} \mathrm{MHCII}\right)$ in the initiation of the immune response has been discussed for the live vaccine, and the similar responses by these cells to both vaccines demonstrate the importance of this first step in the induction of protection. For the inactivated vaccine, the $\mathrm{Kul}^{+} \mathrm{MHCII}{ }^{+}$cells constituted up to 30\% of all blood leucocytes following the second dose administration, which may be due also to the reduction in the percentage of almost all other leucocytes.

There was a concurrent decrease in the percentage of several immune cells after the second inactivated vaccine dose. Another group suggested that the reduced percentage of $\mathrm{CD}^{+}$and $\mathrm{CD} 8^{+}$cells in the peripheral blood following bacterin immunization and Salmonella challenge was due to reduced activation of cellular immunity because infection had been limited by vaccination [28]. It is possible that a different mechanism was involved in the paper cited, since similar results were observed in the present work without bacterial challenge.

Cellular trafficking between secondary immune organs, the injection site and blood/lymph vessels may explain some of the findings of the bacterin immunization. Following a Salmonella challenge, $\mathrm{CD}^{+} \mathrm{CD} 28^{+}$and

Table 2. Local secretory IgA titers following immunization with live (a) or bacterin (b) vaccines. Results are shown as averages of absorbance values. The columns refer to the age of the chickens at the time of blood collection. Statistically significant differences at a given date are shown with different superscript letters next to the averages.

(a)

\begin{tabular}{cccccccccc}
\hline Group & $\mathbf{3 ~ d}$ & $\mathbf{7 ~ d}$ & $\mathbf{1 4} \mathbf{d}$ & $\mathbf{2 1 ~ d}$ & $\mathbf{4 9} \mathbf{d}$ & $\mathbf{5 6 ~ d}$ & $\mathbf{1 1 9} \mathbf{d}$ & $\mathbf{1 2 6} \mathbf{d}$ \\
\hline Control & 0.090 & 0.109 & 0.082 & 0.101 & $0.109^{\mathrm{b}}$ & $0.136^{\mathrm{b}}$ & $0.164^{\mathrm{b}}$ & $0.136^{\mathrm{b}}$ \\
Live vaccine & 0.090 & 0.106 & 0.096 & 0.119 & $0.155^{\mathrm{a}}$ & $0.382^{\mathrm{a}}$ & $0.322^{\mathrm{a}}$ & $0.256^{\mathrm{a}}$ \\
Probability & 0.9135 & 0.8001 & 0.1030 & 0.2989 & 0.0404 & 0.0006 & 0.0005 & $<0.0001$ \\
\hline
\end{tabular}

(b)

\begin{tabular}{ccccccc}
\hline Group & $\mathbf{8 7 ~ d}$ & $\mathbf{9 1 ~ d}$ & $\mathbf{9 8 ~ d}$ & $\mathbf{1 0 5} \mathbf{d}$ & $\mathbf{1 3 3} \mathbf{d}$ & $0.135^{\mathrm{b}}$ \\
Control & 0.145 & $0.141^{\mathrm{b}}$ & $0.083^{\mathrm{b}}$ & $0.213^{\mathrm{b}}$ & $0.129^{\mathrm{b}}$ & $0.462^{\mathrm{a}}$ \\
Bacterin & 0.216 & $0.539^{\mathrm{a}}$ & $0.816^{\mathrm{a}}$ & $0.528^{\mathrm{a}}$ & $0.440^{\mathrm{a}}$ & $<0.0001$ \\
Probability & 0.1912 & $<0.0001$ & $<0.0001$ & 0.0005 & $<0.0001$ \\
\hline
\end{tabular}


$\mathrm{CD} 4^{+} \mathrm{CD} 8^{+}$and $\mathrm{CD} 8^{+} \mathrm{TCRV} \beta 1^{+}$cells are reduced in the peripheral blood, for example, and it is known that lymphocytopenia also occurs [29]. Lymphocytes infiltrate the infection site with $\mathrm{CD}^{+}, \mathrm{CD}^{+}$and TCRV $\beta 1^{+}$ being majorly present [24] [29]-[31].

Subcutaneous bacterin immunization is not commonly a strong stimulus for mucosal IgA production [32]. Following mucosal immunization, only with the concomitant use of liposomes was an inactivated vaccine capable of inducing luminal IgA [25]. In opposition to these findings in the literature, subcutaneous immunization with bacterin rapidly induced local secretory IgA in the present work, even before the second immunization (Table 2(b)). Serum IgY was also increased after both vaccination doses (Table 1(b)), indicating that, although there was a decrease in the percentage of circulating B-lymphocytes, this probably was followed by an enrichment of this cell population in the spleen — which is necessary for strong antibody production-favoring the theory that the cells from the blood were directed to lymphoid sites. The present study confirms results from the literature for IgY production after bacterin immunization, which was correlated elsewhere to lower Salmonella colonization of organs [11].

In summary, bacterin immunization induced an evident reduction in the relative number of several circulating leucocytes, notably with the exception of macrophages, which was also increased following live vaccine immunization. Although these immune cells were reduced in the peripheral blood, they were likely to be involved with protection after being directed to lymphoid and injection sites. Humoral immune responses are likely to be relevant to the protection conferred by the inactivated vaccine, as it was also able to induce high mucosal IgA and seric IgY levels.

The analysis of the fluctuation of immune parameters in the same animals through a long experimental period contributes to the comprehension of how protection is developed within one individual and which cellular/ humoral subsets are relevant for protection.

\section{References}

[1] EFSA (2014) The European Union Summary Report on Trends and Sources of Zoonoses, Zoonotic Agents and FoodBorne Outbreaks in 2012. EFSA Journal, 12, 3547-3859.

[2] Baú, A.C., Carvalhal, J.B. and Aleixo, J.A.G. (2001) Prevalência de Salmonella em produtos de frangos e ovos de galinha comercializados em Pelotas, RS, Brasil. Ciência Rural, 31, 303-307. http://dx.doi.org/10.1590/S0103-84782001000200018

[3] Tessari, E.N.C., Cardoso, A.L.S.P., de Castro, A.G.M. and Zanatta, G.F. (2003) Prevalência de Salmonella enteritidis em carcaças de frango industrialmente processadas. Higiene Alimentar, 17, 52-55.

[4] Santos, D.M.S., Berchieri Jr., A., Fernandes, S.A., Tavechio, A.T. and do Amaral, L.A. (2000) Salmonella em carcaças de frango congeladas. Pesquisa Veterinária Brasileira, 20, 39-42.

http://dx.doi.org/10.1590/S0100-736X2000000100005

[5] Vaz, C.S.L., Streck, A.F., Michael, G.B., Marks, F.S., Rodrigues, D.P., dos Reis, E.M.F., Cardoso, M.R.I. and Canal, C.W. (2010) Antimicrobial Resistance and Subtyping of Salmonella enterica Subspecies Enterica Serovar Enteritidis Isolated from Human Outbreaks and Poultry in Southern Brazil. Poultry Science, 89, 1530-1536. http://dx.doi.org/10.3382/ps.2009-00453

[6] Kottwitz, L.B.M., de Oliveira, T.C.R.M., Alcocer, I., Farah, S., Abrahão, W.M. and dos Prazeres Rodrigues, D. (2009) Avaliação epidemiológica de surtos de salmonelose ocorridos no período de 1999 a 2008 no Estado do Paraná, Brasil. Acta Scientiarum, Health Science, 32, 9-15.

[7] EFSA (2004) Opinion of the Scientific Panel on Biological Hazards on a Request from the Commission Related to the Use of Vaccines for the Control of Salmonella in Poultry. EFSA Journal, 114, 1-74.

[8] Gantois, I., Ducatelle, R., Timbermont, L., Boyen, F., Bohez, L., Haesebrouck, F., Pasmans, F. and van Immerseel, F. (2006) Oral Immunisation of Laying Hens with the Live Vaccine Strains of TAD Salmonella vac E and TAD Salmonella vac T Reduces Internal Egg Contamination with Salmonella Enteritidis. Vaccine, 24, 6250-6255. http://dx.doi.org/10.1016/j.vaccine.2006.05.070

[9] Chacana, P.A. and Terzolo, H.R. (2006) Protection Conferred by a Live Salmonella Enteritidis Vaccine against Fowl Typhoid in Laying Hens. Avian Diseases, 50, 280-283. http://dx.doi.org/10.1637/7463-102705R.1

[10] Johnston, C.E., Hartley, C., Salisbury, A.-M. and Wigley, P. (2012) Immunological Changes at Point-of-Lay Increase Susceptibility to Salmonella enterica Serovar Enteritidis Infection in Vaccinated Chickens. PloS One, 7, e48195. http://dx.doi.org/10.1371/journal.pone.0048195

[11] Wisner, A.L.S., Desin, T.S., Lam, P.K.S., Berberov, E., Mickael, C.S., Townsend, H.G., Potter, A.A. and Köster, W. 
(2011) Immunization of Chickens with Salmonella enterica Subspecies enterica Serovar Enteritidis Pathogenicity Island-2 Proteins. Veterinary Microbiology, 153, 274-284. http://dx.doi.org/10.1016/j.vetmic.2011.05.041

[12] Zhang-Barber, L., Turner, A.K. and Barrow, P.A. (1999) Vaccination for Control of Salmonella in Poultry. Vaccine, 17, 2538-2545. http://dx.doi.org/10.1016/S0264-410X(99)00060-2

[13] Crhanova, M., Hradecka, H., Faldynova, M., Matulova, M., Havlickova, H., Sisak, F. and Rychlik, I. (2011) Immune Response of Chicken Gut to Natural Colonization by Gut Microflora and to Salmonella enterica Serovar Enteritidis Infection. Infection and Immunity, 79, 2755-2763. http://dx.doi.org/10.1128/IAI.01375-10

[14] Fernandes Filho, T., Fávaro Jr., C., Ingberman, M., Beirão, B.C.B., Zanata, S.M., Caron, L.F., Inoue, A. and Gomes, L. (2013) Effect of Spray E. coli Vaccine on the Immunity of Poultry. Avian Diseases, 57, 671-676. http://dx.doi.org/10.1637/10456-112612-ResNote.1

[15] Engvall, E. and Perlmann, P. (1972) Enzyme-Linked Immunosorbent Assay, ELISA III. Quantitation of Specific Antibodies by Enzyme-Labeled Anti-Immunoglobulin in Antigen-Coated Tubes. The Journal of Immunology, 109, 129135.

[16] Van Immerseel, F., De Buck, J., De Smet, I., Mast, J., Haesebrouck, F. and Ducatelle, R. (2002) Dynamics of Immune Cell Infiltration in the Caecal Lamina Propria of Chickens after Neonatal Infection with a Salmonella enteritidis Strain. Developmental \& Comparative Immunology, 26, 355-364. http://dx.doi.org/10.1016/S0145-305X(01)00084-2

[17] Marietto-Gonçalves, G.A., Curotto, S.M.R., Salgado, B.S., Milbradt, E.L. and Andreatti Filho, R.L. (2012) Leucometric Analysis of 1-Day-Old Chicks Inoculated with Salmonella typhimurium or lactobacilli. Comparative Clinical Pathology, 21, 1617-1621. http://dx.doi.org/10.1007/s00580-011-1336-y

[18] Chappell, L., Kaiser, P., Barrow, P., Jones, M.A., Johnston, C. and Wigley, P. (2009) The Immunobiology of Avian Systemic Salmonellosis. Veterinary Immunology and Immunopathology, 128, 53-59. http://dx.doi.org/10.1016/j.vetimm.2008.10.295

[19] Asheg, A.A., Levkut, M., Revajová, V., Evâíková, Z., Kolodzieyski, L. and Pistl, J. (2003) Dynamics of Lymphocyte Subpopulations in Immune Organs of Chickens Infected with Salmonella enteritidis. Acta Veterinaria Brunensis, 72, 359-364. http://dx.doi.org/10.2754/avb200372030359

[20] Pawelec, G., Akbar, A., Caruso, C., Effros, R., Grubeck-Loebenstein, B. and Wikby, A. (2004) Is Immunosenescence Infectious? Trends in Immunology, 25, 406-410. http://dx.doi.org/10.1016/j.it.2004.05.006

[21] Nabeshima, S., Murata, M., Kikuchi, K., Ikematsu, H., Kashiwagi, S. and Hayashi, J. (2002) A Reduction in the Number of Peripheral CD28 ${ }^{+} \mathrm{CD}^{+} \mathrm{T}$ Cells in the Acute Phase of Influenza. Clinical \& Experimental Immunology, 128, 339346. http://dx.doi.org/10.1046/j.1365-2249.2002.01819.x

[22] Olsson, J., Wikby, A., Johansson, B., Löfgren, S., Nilsson, B.-O. and Ferguson, F.G. (2001) Age-Related Change in Peripheral Blood T-Lymphocyte Subpopulations and Cytomegalovirus Infection in the Very Old: The Swedish Longitudinal OCTO Immune Study. Mechanisms of Ageing and Development, 121, 187-201. http://dx.doi.org/10.1016/S0047-6374(00)00210-4

[23] Lundin, B.S., Johansson, C. and Svennerholm, A.-M. (2002) Oral Immunization with a Salmonella enterica Serovar Typhi Vaccine Induces Specific Circulating Mucosa-Homing $\mathrm{CD}^{+}$and $\mathrm{CD}^{+} \mathrm{T}$ Cells in Humans. Infection and Immunity, 70, 5622-5627. http://dx.doi.org/10.1128/IAI.70.10.5622-5627.2002

[24] Carvajal, B.G., Methner, U., Pieper, J. and Berndt, A. (2008) Effects of Salmonella enterica Serovar Enteritidis on Cellular Recruitment and Cytokine Gene Expression in Caecum of Vaccinated Chickens. Vaccine, 26, 5423-5433. http://dx.doi.org/10.1016/j.vaccine.2008.07.088

[25] Fukutome, K., Watarai, S., Mukamoto, M. and Kodama, H. (2001) Intestinal Mucosal Immune Response in Chickens Following Intraocular Immunization with Liposome-Associated Salmonella enterica Serovar Enteritidis Antigen. Developmental \& Comparative Immunology, 25, 475-484. http://dx.doi.org/10.1016/S0145-305X(01)00014-3

[26] Beal, R.K., Powers, C., Wigley, P., Barrow, P.A. and Smith, A.L. (2004) Temporal Dynamics of the Cellular, Humoral and Cytokine Responses in Chickens during Primary and Secondary Infection with Salmonella enterica Serovar Typhimurium. Avian Pathology, 33, 25-33. http://dx.doi.org/10.1080/03079450310001636282

[27] Barrow, P.A. (2007) Salmonella Infections: Immune and Non-Immune Protection with Vaccines. Avian Pathology, 36, 1-13. http://dx.doi.org/10.1080/03079450601113167

[28] Muir, W.I., Bryden, W.L. and Husband, A.J. (1998) Evaluation of the Efficacy of Intraperitoneal Immunization in Reducing Salmonella typhimurium Infection in Chickens. Poultry Science, 77, 1874-1883. http://dx.doi.org/10.1093/ps/77.12.1874

[29] Beirão, B.C.B., Fávaro Jr., C., Nakao, L.S., Caron, L.F., Zanata, S.M. and Mercadante, A.F. (2012) Flow Cytometric Immune Profiling of Specific-Pathogen-Free Chickens before and after Infectious Challenges. Veterinary Immunology and Immunopathology, 145, 32-41. http://dx.doi.org/10.1016/j.vetimm.2011.10.004

[30] Holt, P.S., Vaughn, L.E. and Gast, R.K. (2010) Flow Cytometric Characterization of Peyer’s Patch and Cecal Tonsil T 
Lymphocytes in Laying Hens Following Challenge with Salmonella enterica Serovar Enteritidis. Veterinary Immunology and Immunopathology, 133, 276-281. http://dx.doi.org/10.1016/j.vetimm.2009.08.001

[31] Berndt, A., Pieper, J. and Methner, U. (2006) Circulating Gamma Delta T Cells in Response to Salmonella enterica Serovar Enteritidis Exposure in Chickens. Infection and Immunity, 74, 3967-3978. http://dx.doi.org/10.1128/IAI.01128-05

[32] Tran, T.Q.L., Quessy, S., Letellier, A., Desrosiers, A. and Boulianne, M. (2010) Immune Response Following Vaccination against Salmonella Enteritidis Using 2 Commercial Bacterins in Laying Hens. Canadian Journal of Veterinary Research, 74, 185. 